\title{
Chapter 5 \\ Anaerobic Digestion of Rice Straw for Biogas Production
}

\author{
Nguyen Vo Chau Ngan, Francis Mervin S. Chan, Tran Sy Nam, \\ Huynh Van Thao, Monet Concepcion Maguyon-Detras, \\ Dinh Vuong Hung, Do Minh Cuong, and Nguyen Van Hung
}

\begin{abstract}
Anaerobic digestion (AD) is a process of degradation of organic matter by microorganisms in an oxygen-free environment, which produces biogas, a vital renewable energy source. Using solely an organic source, such as monosubstrates, it is difficult to optimize the AD process due to nutrient imbalance, lack of appropriate microbial communities, and the effect of operational parameters. This chapter reviews the current studies on biogas production from the anaerobic codigestion process of mixing agricultural byproducts, focusing on rice straw and livestock manure as substrates. Because rice straw is high in cellulose, it needs to be pretreated before feeding into the anaerobic digester. Different rice straw pretreatments are summarized including physical, chemical, and biological methods. Current biogas systems are discussed. The utilization of bioslurry from the anaerobic fermentation process to agricultural cultivation and aquaculture activities is also discussed.
\end{abstract}

Keywords Anaerobic digestion $\cdot$ Biogas $\cdot$ Co-digestion $\cdot$ Pre-treatment $\cdot$ Rice straw

N. V. C. Ngan $(\varangle) \cdot$ T. S. Nam $\cdot$ H. Van Thao

Can Tho University, Can Tho, Vietnam

e-mail: nvcngan@ctu.edu.vn; tsnam@ctu.edu.vn; hvthao@ctu.edu.vn

F. M. S. Chan

University of the Philippines Los Baños, Los Baños, Philippines

e-mail: f.chan@irri.org

M. C. Maguyon-Detras

Department of Chemical Engineering, College of Engineering

and Agro-Industrial Technology, University of the Philippines Los Baños (UPLB),

Los Baños, Laguna, Philippines

e-mail:mmdetras@up.edu.ph

D. V. Hung · D. M. Cuong

Hue University, Hue, Vietnam

e-mail: dominhcuong@huaf.edu.vn

N. V. Hung

International Rice Research Institute (IRRI), Los Baños, Laguna, Philippines

e-mail: hung.nguyen@irri.org 


\subsection{Introduction of Anaerobic Digestion Technology}

\subsubsection{Products of Anaerobic Digestion}

Biogas is one of the major products of the anaerobic digestion (AD) of organic substances and is considered an alternative green energy resource. It is a mixture of gases of which the composition depends on substrates and AD process conditions such as temperature, $\mathrm{pH}$, and retention time. Biogas mixture mainly consists of $\mathrm{CH}_{4}, \mathrm{CO}_{2}, \mathrm{O}_{2}, \mathrm{~N}_{2}, \mathrm{H}_{2} \mathrm{~S}$, and even other gas compositions. Methane $\left(\mathrm{CH}_{4}\right)$ is the most important component of biogas because it has the highest energy density among the biogas components. Therefore, the high $\mathrm{CH}_{4}$ content of biogas is desired. Examples of biogas composition from different substrates or sources are shown in Table 5.1.

Biogas technology is applicable to small-scale and large-scale uses including electricity generation.

Biogas can also be upgraded into biomethane or renewable natural gas (RNG), which is like natural gas that comes from fossil fuels. Its methane content is $90 \%$ or greater. RNG can be substituted for natural gas and can be used as fuel for vehicles that run on natural gas and to supply gas to natural gas grid.

Aside from biogas, the other AD byproduct is digestate. It can be solid or liquid and contains considerable amounts of nitrogen (in ammonium form), macronutrients, and micronutrients that can supplement plant growth (Makádi et al. 2012). Depending on the feedstock of AD, digestate can be utilized as an organic fertilizer or as a compost ingredient. Digestate that uses plant and animal-based feedstocks can be used directly as a fertilizer. One example is the VACB model (ㄴườn/GardenAo/Pond-Chuồng/Pigsty-Biogas) of Vietnam (Thanh 2010). Digestate from the AD process that uses an organic fraction of municipal waste as feedstock will need further processing or will need to be disposed of in a landfill because of possible high levels of heavy metals, pathogens, and other toxic substances.

Table 5.1 The composition of biogas obtained from organic substances

\begin{tabular}{|c|c|c|c|c|c|c|}
\hline \multirow[b]{2}{*}{ Sources } & \multicolumn{5}{|c|}{ The composition of biogas (\%) } & \multirow[b]{2}{*}{ Sources } \\
\hline & $\mathrm{CH}_{4}$ & $\mathrm{CO}_{2}$ & $\mathrm{O}_{2}$ & $\mathrm{~N}_{2}$ & $\mathrm{H}_{2} \mathrm{~S}$ & \\
\hline \multirow[t]{3}{*}{ Landfills } & $47-57$ & $24-29$ & $<1$ & $1-17$ & $<0.1$ & Rasi et al. (2007) \\
\hline & $37-62$ & $24-29$ & $<1$ & - & - & Allen et al. (1997) \\
\hline & $45-55$ & $30-40$ & - & $51-5$ & - & Jönsson et al. (2003) \\
\hline \multirow[t]{3}{*}{ Plant biomass } & $55-58$ & $37-38$ & $<1$ & $<1-2$ & - & Rasi et al. (2007) \\
\hline & $48-65$ & $36-41$ & $<1$ & $<17$ & $<0.1$ & Rasi et al. (2007) \\
\hline & $45-54$ & - & - & - & - & Tran et al. (2014) \\
\hline \multirow[t]{2}{*}{ Sludge } & $55-65$ & $35-45$ & - & $<1$ & - & Jönsson et al. (2003) \\
\hline & 57.8 & 38.6 & 0 & $3-7$ & $<0.1$ & Spiegel and Preston (2003) \\
\hline \multirow[t]{2}{*}{ Pig manure } & $55-65$ & $35-45$ & - & $0-3$ & - & Polprasert and Koottatep (2007) \\
\hline & $42-59$ & - & - & - & - & Tran et al. (2014) \\
\hline
\end{tabular}




\subsubsection{Anaerobic Digestion Process}

$\mathrm{AD}$ is a biological process that degrades organic material by the concerted actions of a wide variety of microbial communities in the absence of oxygen. In a simplified description, AD is divided into four phases (Fig. 5.1): hydrolysis, acidogenesis (acid-producing), acetogenesis (acetic acid-producing), and methanogenesis (methane-producing).

\subsubsection{Stage 1: Hydrolysis}

Insoluble organic compounds, such as cellulose, protein, fat, and some insoluble forms of organic compounds, are decomposed by enzymes (produced by bacteria) and anaerobic bacteria. Small soluble organic molecules, which are produced in this stage, are the raw material for the bacteria in the next stage. Hydrolysis of carbohydrates can occur within a few hours, while protein and fat hydrolysis may take several days. However, lignocellulose and lignin substances decompose slowly and incompletely (Deublein and Steinhauser 2011). Facultative anaerobes consume dissolved oxygen in water, which results in reduction of redox potential that is favorable to the $\mathrm{AD}$ process. In this stage, carbohydrates are broken down into simple

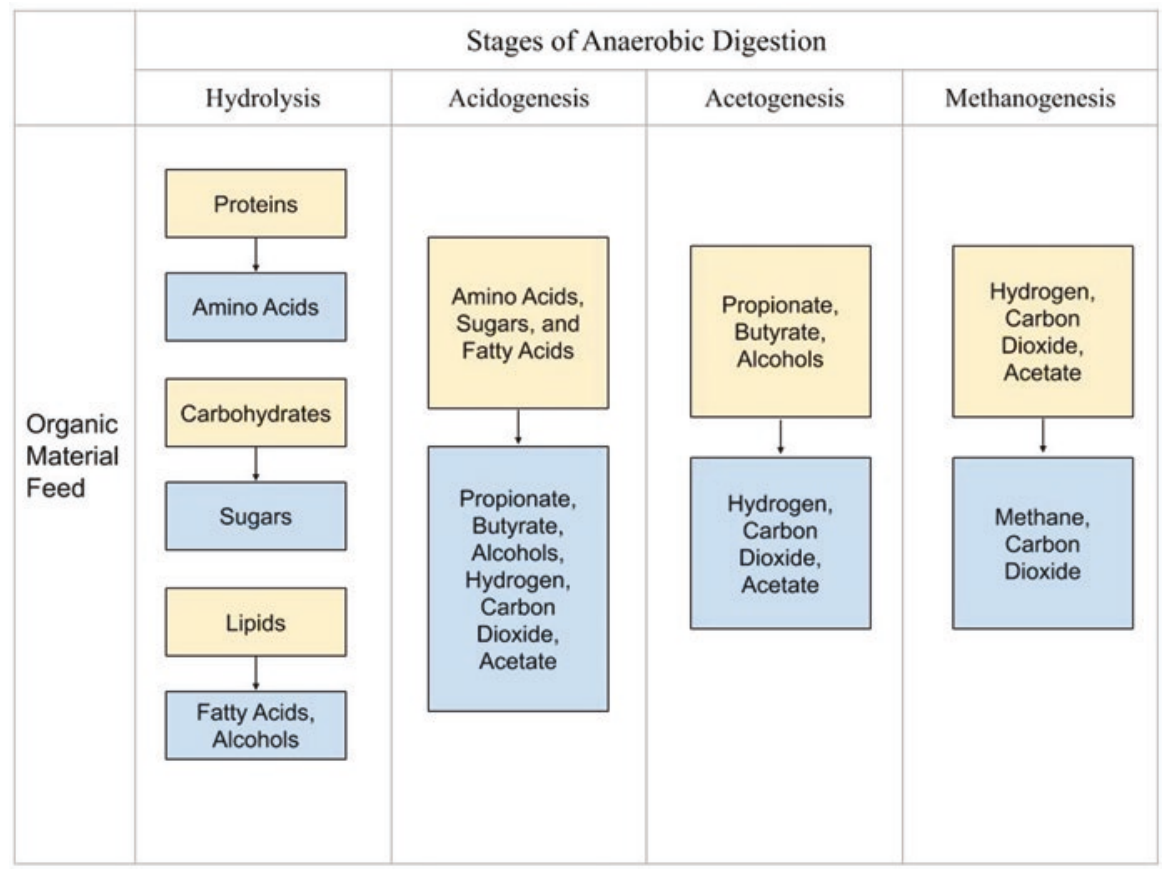

Fig. 5.1 Four stages of methane production. (Adapted from Zinder (1993)) 
sugars; fats degrade into fatty acids; and proteins degrade into amino acids (Gerardi 2003; Eastman and Ferguson 1981).

\subsubsection{Stage 2: Acid-Producing (Acidogenesis)}

Simple organic compounds which were created during hydrolysis stage will be transformed into volatile fatty acids (VFAs), long chain fatty acids, propionate, and butyrate by anaerobes (Jördening and Winter 2006). The concentration of $\mathrm{H}^{+}$formed in this stage may affect the products of fermentation. High concentration of $\mathrm{H}^{+}$ reduces the production of acetate. In general, during this stage, simple sugars, fatty acids, and amino acids are fermented to form organic acids and alcohol (Gerardi 2003).

\subsubsection{Stage 3: Acetic Acid-Producing (Acetogenesis)}

The products from the previous stage are the substrate for bacteria in the acetic acidproducing stage. The products from these intermediate substrates are $\mathrm{H}_{2}, \mathrm{CO}_{2}$, and acetate. Acetogenic bacteria grow together with methanogen bacteria in this stage.

\subsubsection{Stage 4: Methane-Producing (Methanogenesis)}

During this stage, methane is created under completely anaerobic conditions. This reaction is considered an exothermic reaction. Stage 4 can be divided into two methane-generating processes: reduction of $\mathrm{CH}_{3} \mathrm{COO}^{-}$and conversion of $\mathrm{H}_{2}$ with $\mathrm{CO}_{2}$. Acetotrophic methanogens are responsible for the reduction of acetate $\left(\mathrm{CH}_{3} \mathrm{COO}^{-}\right)$into methane, while hydrogenotrophic methanogens are responsible for converting $\mathrm{H}_{2}$ and $\mathrm{CO}_{2}$ into methane (Ziemiński and Frąc 2012). Some of the reactions during methanogenesis are described in Table 5.2.

Table 5.2 Some methanogenesis reactions

\begin{tabular}{l|l|l}
\hline Reactants & Products & Organisms involved \\
\hline $4 \mathrm{H}_{2}+\mathrm{HCO}_{3}{ }^{-}+\mathrm{H}^{+}$ & $\mathrm{CH}_{4}+3 \mathrm{H}_{2} \mathrm{O}$ & Most methanogens \\
\hline $4 \mathrm{HCO}_{2}^{-}+\mathrm{H}^{+}+\mathrm{H}_{2} \mathrm{O}$ & $\mathrm{CH}_{4}+3 \mathrm{HCO}_{3}^{-}$ & Many hydrogenotrophic methanogens \\
\hline $2 \mathrm{CH}_{3} \mathrm{COOH}+\mathrm{HCO}_{3}^{-}$ & $\begin{array}{l}2 \mathrm{CH}_{3} \mathrm{COO}^{-}+\mathrm{H}^{+}+ \\
\mathrm{CH}_{4}+\mathrm{H}_{2} \mathrm{O}\end{array}$ & Methanosarcina and Methanothrix \\
\hline $4 \mathrm{CH}_{3} \mathrm{OH}$ & $3 \mathrm{CH}_{4}+\mathrm{HCO}_{3}{ }^{-}+\mathrm{H}_{2} \mathrm{O}+\mathrm{H}^{+}$ & $\begin{array}{l}\text { Methanosarcina and other methylotrophic } \\
\text { methanogens }\end{array}$ \\
\hline
\end{tabular}

Source: Zinder (1993) 
Table 5.3 Factors that affect the $\mathrm{AD}$ process

\begin{tabular}{l|l|l}
\hline Factors & Range & Optimum value for methane production \\
\hline Temperature & $<20-60{ }^{\circ} \mathrm{C}$ & $35^{\circ} \mathrm{C}$ \\
\hline $\mathrm{pH}$ & $6.6-7.6$ & 7.0 \\
\hline Redox potential & $\leq 150 \mathrm{mV}$ & $\leq 250 \mathrm{mV}$ \\
\hline Salinity & $0-8 \%$ & $0.84 .5 \%$ \\
\hline C/N ratio & $20-40$ & $20-30$ \\
\hline Loading rate & $1-4 \mathrm{~kg} \mathrm{VS} \mathrm{m}^{3} \mathrm{day}^{-1}$ & $1-4 \mathrm{~kg} \mathrm{VS} \mathrm{m}^{3}$ day $^{-1}$ \\
\hline Retention time & $10-60$ days & $10-30$ days \\
\hline
\end{tabular}

\subsubsection{Factors Affecting the Anaerobic Digestion Process}

The AD process is affected by different factors that include operation parameters, type of feedstock, rate of feed of feedstock, etc. Some factors are enumerated in Table 5.3 and discussed below.

\subsubsection{Temperature}

Depending on the microorganisms involved, the anaerobic reactors operate in specifuied temperature regimes:

- Psychrophilic anaerobic digestion $\left(<20^{\circ} \mathrm{C}\right)$

- Mesophilic anaerobic digestion $\left(20-45^{\circ} \mathrm{C}\right)$

- Thermophilic anaerobic digestion $\left(46-60^{\circ} \mathrm{C}\right)$

The activity of methane-forming bacteria is strongly influenced by temperature. In general, when the temperature increases, biogas production increases. For that reason, digesters are heated in colder regions, such as Europe. But at a temperature range of $40-50{ }^{\circ} \mathrm{C}$, biogas production will decrease because this temperature range is not suitable for both mesophilic and thermophilic bacteria. If the temperature is above $60{ }^{\circ} \mathrm{C}$, biogas production decreases and it stops completely at $65^{\circ} \mathrm{C}$ or higher. Biogas production is at its maximum rate when the temperature is kept at $35^{\circ} \mathrm{C}$ (Chandra et al. 2012), while optimum temperatures for methane production range from 35 to $40{ }^{\circ} \mathrm{C}$ (Lianhua et al. 2010).

The most appropriate temperature is $30-40{ }^{\circ} \mathrm{C}$. Low temperatures, abrupt changes in the system, or both weaken methanogen activities (Yadvika et al. 2004; Nozhevnikova et al. 1999).

Temperature is a very important variable for efficient anaerobic digestion of rice straw. Maximized methane production and economic input depend on it. 


\subsubsection{2 pH and Alkalinity}

McCarty (1964) determined that the biological process of AD works optimally in a pH environment of 6.6-7.6. However, Yadvika et al. (2004) and Gerardi (2003) reported that the optimum $\mathrm{pH}$ range for $\mathrm{AD}$ is at 6.8-7.2. At a $\mathrm{pH}$ lower than 5.5, acidogenic bacteria are still active but methanogenic bacteria are inhibited. Inhibition of methanogenic bacteria lowers the methane content of the biogas; therefore, low $\mathrm{pH}$ conditions are avoided. During the AD process, $\mathrm{pH}$ will usually drop lower than 6.6 if there is excessive accumulation of fatty acids in the acidogenesis stage. Decrease in $\mathrm{pH}$ is caused by either overloading of substrates or because the toxins in the feedstock inhibit the activity of methanogens. In this case, substrate feed must be stopped so that acid production will stop or decrease and acetogens and methanogens will be able to degrade excess acid that was produced. Another solution is to use lime for neutralizing the acid and increase the $\mathrm{pH}$ to an optimum range. An increase in $\mathrm{pH}$ (greater than 8.0) also has an inhibitory effect on AD. At pH 9.0, the methanogenesis process completely stops (Clark and Speece 1971).

Alkalinity is a measure of the capacity of a solution to neutralize acid. Bicarbonate $\left(\mathrm{HCO}_{3}{ }^{-}\right)$, carbonate $\left(\mathrm{CO}_{3}{ }^{2-}\right)$, and hydroxide $\left(\mathrm{OH}^{-}\right)$are the ions that are used to increase alkaline conditions in the digester. Alkalinity is also considered as the buffering capacity of a solution and is essential for controlling and maintaining a stable $\mathrm{pH}$ for the anaerobic digestion process. High alkalinity conditions (1500-3000 mg $\mathrm{CaCO}_{3} \mathrm{~L}^{-1}$ ) enhance the $\mathrm{pH}$ stability of the anaerobic digestion process (Gerardi 2003).

\subsubsection{Redox Potential}

The redox potential is a measure of oxidation capacity or reducing capacity. Biogas is produced effectively in an anaerobic environment where the redox potential must be less than $-150 \mathrm{mV}$. Redox always reaches a negative value (less than $-100 \mathrm{mV}$ ) under anaerobic conditions (Wiese and König 2009).

In general, the use of substrates including oxygen, nitrate and sulfate promotes oxidation that can significantly change the redox potential and cause changes in $\mathrm{pH}$. Redox potential can be used to predict impending changes in $\mathrm{pH}$ of the digester (Wiese and König 2009).

Methane begins to form and $\mathrm{CO}_{2}$ and $\mathrm{H}_{2}$ are converted into $\mathrm{CH}_{4}$ when the redox value is less than $-250 \mathrm{mV} ; \mathrm{H}_{2} \mathrm{O}$ and $\mathrm{H}_{2} \mathrm{~S}$ are produced when the redox value is less than $-150 \mathrm{mV}$ (Laanbroek 1990).

\subsubsection{Salinity}

High salinity and ammonium concentrations have detrimental effects on biological processes such as anaerobic digestion (Fang et al. 2011; Chen et al. 2008; Reinhart and Townsend 1998; Kargi and Dincer 1996). High salt concentrations dehydrate 
bacterial cells due to osmotic pressure (Alhraishawi and Alani 2018). Salt toxicity is determined mostly by the type of cation the salt has.

Feedstock inflow to anaerobic digesters usually contains light metal ions, namely, sodium, potassium, calcium, and magnesium. These cations may also be liberated during the AD process (Chen et al. 2007). A study by Albraishawi and Alani (2018) on codigestion of food waste demonstrated that increasing salt concentrations $(0$, 16,30 , and $60 \mathrm{~g} \mathrm{NaCl} \mathrm{L}^{-1}$ ) has a negative effect on the volume of biogas produced $\left(45,21,5\right.$, and $\left.2 \mathrm{ml} \mathrm{d}^{-1}\right)$. In terms of methane yield, a study by Lee et al. (2009) on anaerobic digestion of leachate from a food waste recycling facility showed that low-salt concentrations $\left(0.5\right.$ and $\left.2 \mathrm{~g} \mathrm{NaCl} \mathrm{L}^{-1}\right)$ increase methane yield, but higher salt concentrations ( 5 and $10 \mathrm{~g} \mathrm{NaCl} \mathrm{L}^{-1}$ ) resulted in a decrease in methane yield (36 and $41 \%$ reduction).

Anwar et al. (2016) showed that methane yield inhibition in anaerobic digestion of food waste is negligible at salt concentrations of $8 \mathrm{~g} \mathrm{NaCl} \mathrm{L}^{-1}$, but salt concentrations greater than $8 \mathrm{~g} \mathrm{Nacl} \mathrm{L}^{-1}$ resulted in a sharp decline in methane yield. The cubic regression model $y=0.508+2.401 x-0.369 x^{2}+0.033 x^{3}$ was derived from this experiment to describe sodium salt inhibition, where $y$ is the methane yield and $\mathrm{x}$ is the sodium salt concentration. This model predicted experimental results with a small discrepancy of $10 \%$. A study by Ogata et al. (2016) on the effect of salt on biogas production of leachate in a waste landfill showed that methane production decreased while carbon dioxide production was unchanged at a salt concentration of $35 \mathrm{~ms} \mathrm{~cm}^{-1}$ (approximately $19 \mathrm{mg} \mathrm{L}^{-1}$ ). A salt content of $80 \mathrm{~ms} \mathrm{~cm}^{-1}$ (approximately $44 \mathrm{mg} \mathrm{L}^{-1}$ ) decreased production of both methane and carbon dioxide. Based on these studies on salt inhibition of the anaerobic digestion process, it can be inferred that low salt concentrations in the AD reactant mixture (up to $2 \mathrm{~g} \mathrm{~L}^{-1} \mathrm{NaCl}$ ) increase methane yield, but higher salt concentrations (greater than $5 \mathrm{~g} \mathrm{~L}^{-1} \mathrm{NaCl}$ ) decrease methane yield.

\subsubsection{Carbon to Nitrogen $(\mathrm{C} / \mathrm{N})$ Ratio}

The quality of biogas produced by anaerobic digestion is determined by the growth of the community of bacteria in the digester. The optimal carbon to nitrogen $(\mathrm{C} / \mathrm{N})$ ratio for bacteria to grow is in the range of 20-30 because the bacteria use up carbon 20 to 30 times quicker than nitrogen (Bardiya and Gaur 1997; Malik et al. 1987). If the $\mathrm{C} / \mathrm{N}$ ratio is higher than optimal, the decomposition rate will be slower. When the $\mathrm{C} / \mathrm{N}$ ratio is low, the accumulation of ammonia can occur, which can inhibit the activity of bacteria. Some substrates for $\mathrm{AD}$ with different $\mathrm{C} / \mathrm{N}$ ratios are shown in Table 5.4.

The difference in $\mathrm{C} / \mathrm{N}$ ratios show that plant materials have a high $\mathrm{C} / \mathrm{N}$ ratio and animal manures have a low one. To achieve the optimum $\mathrm{C} / \mathrm{N}$ ratio of $20 / 1-30 / 1$, plant material and animal manures are codigested.

The $\mathrm{C} / \mathrm{N}$ ratio is a critical factor in the anaerobic digestion process, which shows the balance of nutrients of input materials. Depending on the type of paddy rice, untreated rice straw has a low concentration of total $\mathrm{N}$ content, even less than $1 \%$ of 
Table 5.4 C/N ratio of some AD substrates

\begin{tabular}{l|l|l}
\hline Organic source & C/N ratio & Source \\
\hline Rice straw & $44.0-74.2$ & $\begin{array}{l}\text { Li et al. (2015), Gu et al. (2014), Ye et al. (2013); } \\
\text { Lim et al. (2012), Hills (1981) }\end{array}$ \\
\hline Water hyacinth & $12-42$ & Ngan et al. (2011) \\
\hline Cow manure & $13.0-14.2$ & Biosantech et al. (2013), Hills (1981) \\
\hline Pig manure & $7.0 ; 10.8$ & Biosantech et al. (2013), Hills (1981) \\
\hline Chicken manure & $4.4 ; 7.0$ & Biosantech et al. (2013), Hills (1981) \\
\hline
\end{tabular}

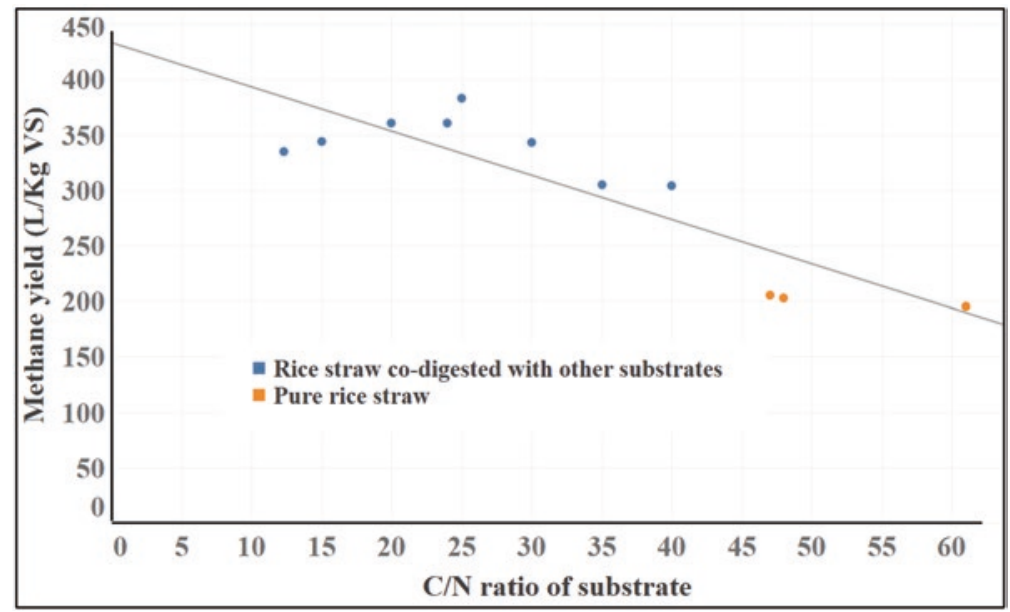

Fig. 5.2 Effect of the $\mathrm{C} / \mathrm{N}$ ratio on methane yield of rice straw. (Sources: Yan et al. (2015), Ye et al. (2013), Menardo et al. (2012), Dinuccio et al. (2010), and Hills (1981))

dry basis (Dinuccio et al. 2010; Lei et al. 2010). The typical C/N ratios for untreated rice straw are approximately from 40 to 80 (Tran et al. 2014; Arvanitoyannis and Tsherkezou 2008; Ghosh and Bhattacharyya 1999). The effect of the $\mathrm{C} / \mathrm{N}$ ratio on methane yield is illustrated in Fig. 5.2, which demonstrates that methane yield increases when $\mathrm{C} / \mathrm{N}$ ratio reaches the optimum range (20/1-30/1) and decreases when the $\mathrm{C} / \mathrm{N}$ ratio rises beyond the optimum.

\subsubsection{Loading Rate and Hydraulic Retention Time (HRT)}

The AD process is affected by the loading rate, represented by chemical oxygen demand per cubic meter per day $\left(\mathrm{COD} \mathrm{m}^{-3} \mathrm{day}^{-1}\right)$ or volatile solids per cubic meter per day (VS m${ }^{-3}$ day $^{-1}$ ), and hydraulic retention time (HRT) of the fermentation mixture. A high organic loading rate will cause accumulation of fatty acids at stage 
3, which negatively affects the production of methane. A low organic loading rate on the other hand will produce low volumes of biogas that will make AD operation uneconomical. The recommended organic loading rate for an anaerobic tank without medium is $1-4 \mathrm{~kg} \mathrm{~V} \mathrm{~m}^{-3}$ day $^{-1}$ (Eder et al. 2006). HRT is the time that the substrates stay inside the anaerobic digester reactor. HRT strongly depends on the substrates and it usually varies from 30 to 60 days. In general, 30 days are typical HRT for nonstirring digesters, the digesters with high decomposition rates can be reduced to an HRT of 10-20 days.

\subsubsection{Toxins}

Biogas production happens in the absence of oxygen; therefore, the presence of oxygen will inhibit the process. In this case, oxygen is considered to be toxic to anaerobic bacteria. In addition, there are many substances that are potentially toxic to microorganisms. Toxic substances and their toxic doses are presented in Table 5.5.

\subsubsection{Dry Matter and Water Content}

The percentage of dry matter content in a digester suitable for biogas generation and solids reduction is about $9-10 \%$. The concentration of dried matter up to $20 \%$ helps to save $50 \%$ of the volume of digesters but may lead to souring (reduction of $\mathrm{pH}$ ) and consequently, reduction of biogas output. Monnet (2003) recommended that the organic dry matter content of batch digester should be adjusted to a range of from $5 \%$ to $10 \%$.

Table 5.5 Toxic dose of substances on AD

\begin{tabular}{l|l|l}
\hline Substances & Toxic dose for AD bacteria & Sources \\
\hline Volatile fatty acids & $>10,000 \mathrm{mg} \mathrm{L}^{-1}$ & Wang et al. (2009) \\
\hline Oleate & $>1700 \mathrm{mg} \mathrm{L}^{-1}$ & Angelidaki and Ahring (1992) \\
\hline Stearate & $>1000 \mathrm{mg} \mathrm{L}^{-1}$ & Angelidaki and Ahring (1992) \\
\hline $\mathrm{NH}_{3}$ & $>16,000 \mathrm{mg} \mathrm{L}^{-1}$ & Koster and Lettinga (1988) \\
\hline $\mathrm{S}_{2}^{-}$ & $>145 \mathrm{mg} \mathrm{L}^{-1}$ & Parkin et al. (1990) \\
\hline $\mathrm{Ca}$ & $>7000 \mathrm{mg} \mathrm{L}^{-1}$ & Ahn et al. (2006) \\
$\mathrm{Mg}$ & $>1000 \mathrm{mg} \mathrm{L}^{-1}$ & Gerardi (2003) \\
$\mathrm{K}$ & $>8000 \mathrm{mg} \mathrm{L}^{-1}$ & Kugelman and McCarty (1965) \\
\hline $\mathrm{Na}$ & $>3500 \mathrm{mg} \mathrm{L}^{-1}$ & Gerardi (2003) \\
\hline $\mathrm{Fe}$ & $>5 \mathrm{mg} \mathrm{L}^{-1}$ & Gerardi (2003) \\
\hline
\end{tabular}




\subsubsection{Stirring}

Stirring maximizes contact of bacteria with organic waste to accelerate the digestion process. It also minimizes the solids deposition on the bottom of the digesters and avoids foaming and scum on the fermentation solution surface.

Without stirring, the substrate in the digester is usually stratified into three layers: the upper layer is the floating layer; the middle layer is fermentation solution; the bottom layer is the sediment layer (Fig. 5.3). Bacteria not distributed evenly in fermentation solution result in uneven contact of bacteria with the substrates. There are many "dead zones" in the digester where the bacteria density is very low and the decomposition is weak. Organic materials can accumulate and settle in those zones. Stirring can overcome the above disadvantages and enhance the decomposition process.

During the digestion process, it is necessary to mix the substrates in the digester, especially for the substrate from plant biomass, to avoid scum formation. Mixing increases the contact between bacteria and substrate and improves decomposition. Mixing can also prevent foaming and make the temperature uniform inside the digester. However, a fast mixing speed will break down the microbial population, thus it is best to stir at lower mixing speeds (Monnet 2003).

\subsubsection{Feedstock Pretreatment}

Fibrous substrates-especially straw, grass, weeds, and stalks-are difficult to decompose and must be treated before digestion. Pretreatment aims to reduce the crystallization of cellulose, increase the surface area of the substrate, and make cellulose more accessible to enzymes that convert carbohydrates into fermentable

Fig. 5.3 Layers in an unstirred anaerobic digester

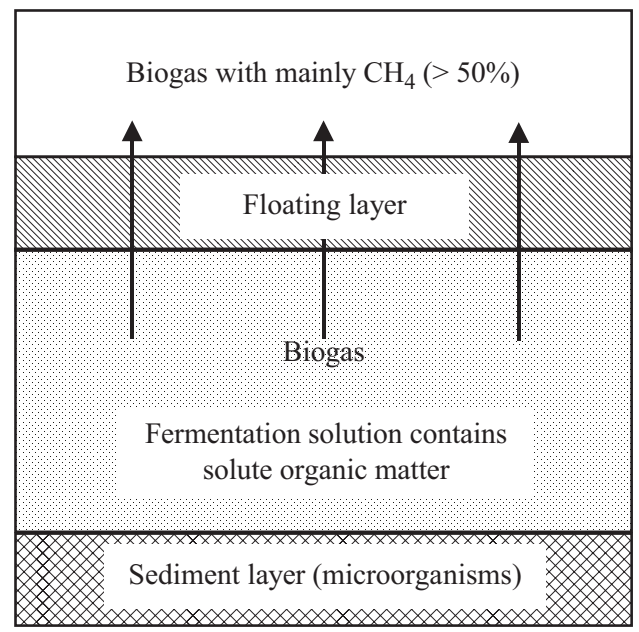


sugars. Pretreatment includes physical, chemical, biological, and their combinations (Alvira et al. 2010).

The anaerobic fermentation process can be enhanced if the digestate is recycled and mixed with substrate feed. The solids content of feeding materials should be adjusted to $5-10 \%$.

\subsubsection{Feedstock Size}

Feeding material size is one of the factors affecting biogas production. Materials should not be too large because it will lead to digester blockage and will also make it difficult for bacteria to decompose. Small-sized materials will have larger surface areas and increased microbial activity, resulting in faster decomposition. According to Sharma et al. (1988),when substrates having five different particle sizes $(0.088$, $0.4,1.0,6.0$, and $30.0 \mathrm{~mm}$ ) were digested and their biogas output were compared, it was shown that the optimal size for producing biogas was 0.088 and $0.4 \mathrm{~mm}$. Some other studies also suggested that a physical pretreatment method, such as grinding and chopping, can significantly reduce digester size design as compared with digesters using untreated substrates, without reducing the biogas production (Moorhead and Nordstedt 1993; Gollakota and Meher 1988).

\subsection{AD Systems}

\subsubsection{Small-Scale Biogas Digesters}

Small-scale biogas plants have mostly been popularized in developing countries. In many of those countries, massive government-led (China, India) or governmentNGO biogas programs were initiated with the aim of popularizing this technology.

Based on the construction methodology, there are two main types of plants including:

- Constructed on-site plants: these plants are often made of brick, mortar and concrete.

- Prefabricated plants (PBD): these plants are produced off-site and installed at the farms. They are made of fiber-reinforced plastic (FRP), tubular (known as bag plants or soft plastic plants), and hard plastics, such as hard polyvinyl chloride (PVC), acrylonitrile butadiene styrene (ABS), high-density polyethylene (HDPE), linear low-density polyethylene (LLDPE), and modified plastics. 


\subsubsection{Biogas Plants Constructed On-Site}

These plants include widely developed and used technologies such as fixed-dome, Indian, and floating drum digester types shown in Fig. 5.4a-c, respectively. Features of these digester types are described in Table 5.6.

\subsection{Fixed-Dome Digesters}

The archetype of all the on-site constructed hydraulic biodigesters is the water pressure digester of Luo Guorui developed in the 1920s in Taiwan (Nianguo 1984). This design eventually led to the Chinese fixed-dome digester. The gas pressure varies

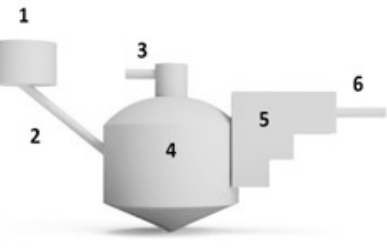

(a)

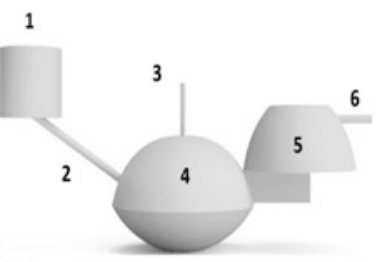

(b)

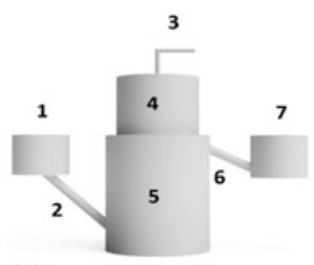

(c)

Fig. 5.4 (a) Chinese-style fixed dome digester, (b) Indian-style fixed dome digester, (c) Floating drum digester. 1 = Feedstock mixing tank, $2=$ Inlet pipe, $3=$ Biogas outlet, $4=$ Digester, $5=$ Displacement chamber, $6=$ Slurry outlet pipe, $7=$ Sludge collection tank

Table 5.6 Comparison of digester plants constructed on-site

\begin{tabular}{|c|c|c|}
\hline Digester type & Advantages & Disadvantages \\
\hline \multirow[t]{2}{*}{$\begin{array}{l}\text { Top manhole } \\
\text { (Chinese plant types) }\end{array}$} & $\begin{array}{l}\text { Easy to enter the digester } \\
\text { from the top }\end{array}$ & $\begin{array}{l}\text { Top manhole is situated on top of } \\
\text { gasholder and is prone to leakages }\end{array}$ \\
\hline & $\begin{array}{l}\text { Can withstand high } \\
\text { pressures, therefore, can } \\
\text { store more gas }\end{array}$ & $\begin{array}{l}\text { Gas proofing of the dome requires special } \\
\text { paints and skilled masons }\end{array}$ \\
\hline \multirow[t]{2}{*}{$\begin{array}{l}\text { Manhole at the outlet } \\
\text { (Deenbandhu, Janata) }\end{array}$} & $\begin{array}{l}\text { Has the highest load bearing } \\
\text { capacity as the dome is a } \\
\text { closed solid structure }\end{array}$ & $\begin{array}{l}\text { Gas proofing of the dome requires special } \\
\text { paints and skilled masons }\end{array}$ \\
\hline & $\begin{array}{l}\text { Cheaper than Chinese } \\
\text { digester models due to } \\
\text { optimized shape }\end{array}$ & \\
\hline \multirow[t]{3}{*}{ Floating drum } & Drum is gastight & $\begin{array}{l}\text { Higher investment and additional } \\
\text { transport cost of drum }\end{array}$ \\
\hline & $\begin{array}{l}\text { Lower masonry skill } \\
\text { requirement }\end{array}$ & $\begin{array}{l}\text { Distance between inlet and outlet is } \\
\text { relatively short which can result in } \\
\text { preferential flow of manure shortening the } \\
\text { HRT }\end{array}$ \\
\hline & & $\begin{array}{l}\text { High depth to width ratio which makes } \\
\text { construction difficult in certain soils }\end{array}$ \\
\hline
\end{tabular}


depending on the amount of slurry accumulated in the displacement tank (or compensation / hydraulic chamber). The pressure is at its highest when the gasholder is full of gas when an equivalent volume of slurry is push upward into the displacement tank; and the pressure is 0 when all gas is used. Gas pressure typically varies between 2 and $15 \mathrm{kPa}$ (Gunnerson et al. 1986).

\subsection{Indian Digesters}

The Deenbandhu digester is the archetype of all fixed-dome digesters with a manhole at the outlet tank. The digester can resist higher structural forces compared to the Chinese digester types as the dome is a closed structure. Another advantage is that the gasholder is closed that reduces the risk of leaks compared to a Chinese digester, which has a manhole at the top of the gasholder (Balasubramaniyam et al. 2008).

\subsection{Floating Drum Digesters}

The floating drum digester was introduced by the Khadi and Village Industry Commission and was later branded as the KVIC digester (Singh and Sooch 2004). The floating drum digester is fed semicontinuously and has a relatively high depthto-width ratio. A barrier is placed in the middle of the digester to promote mixing and prevent short-circuiting (direct substrate flow from the entrance to the exit) (Gunnerson et al. 1986). Biogas accumulates at the headspace of a movable inverted steel drum that serves as the upper part of the digester.

\subsubsection{Prefabricated On-Site Biogas Plants}

\subsection{Fiber-Reinforced Plastic (FRP) Digesters}

The technical designs of fixed-dome FRP biodigesters can be classified in different ways according to the major features of the digester, such as the full FRP digester and the partial FRP digester (usually upper-dome part only) based on the integrity of FRP structural materials; top-mounted hydraulic chamber and lateral-placed hydraulic chamber based on the placement of hydraulic (displacement) chamber; spherical, ellipsoidal, and cylindrical based on the shape of digester body; modular type and integral type based on assembly work; and differences in digester volume. Sizes of these plants are typically in the range of $4-9 \mathrm{~m}^{3}$. 


\subsection{Hard-Plastic Digester Types}

The most common processes used to produce hard-plastic biodigesters are rotation and injection molding. Injection molding machines are more expensive, but the process allows for more intricate shapes, can utilize more types of materials, and is much faster, resulting in lower production costs. Materials used include hard PVC, ABS, HDPE, LLDPE, and modified plastics.

\subsection{Soft-Plastic Digester Types}

The archetype of soft-plastic digester types is the Taiwanese bag digester, which was developed in the 1960s. It is a popular model especially in Central and South America (Gunnerson et al. 1986). The digester is made of a cylindrical plastic tank (tube) nested horizontally on a hardened layer of masonry, concrete, sand, or mud (Gunnerson et al. 1986). A great advantage of the bag digester is the simple design and low material costs. However, these low-cost materials often break down easily and often render the effective lifespan of the digester to less than 2 years. In the last decade, SP digester designs emerged that use higher-quality materials, such as geomembranes and HDPE instead of polyethylene. Such digesters are durable and should have a lifespan of from 6 to 10 years. Lower-quality soft-plastic digesters made from simple PE sheets are also available. These digesters are cheap, but are easily damaged and require frequent repairing and, as such, are not actively promoted.

\subsubsection{Medium- and Large-Scale Plants}

Two-stage AD is widely used for medium- and large-scale biogas plants with the two digester tanks in series. The advantage of having two stages for AD is the separation of the methanogenesis stage from the acidogenesis stage because acids produced in the acidogenesis stage can inhibit the methanogens. The first tank is optimized for hydrolysis and acidogenesis and the second tank is optimized for acetogenesis and methanogenesis. An example of the two-stage AD power plant is presented in Sect. 5.3.2.2.

Medium- and large-scale biogas plants are used on commercial farms and often produce more biogas than the farming households can use. Consequently, biogas is turned into electricity or supplied to gas grids or fuel stations after being upgraded to a desired purity. Most of the large-scale biogas plants are constructed in Germany, USA, UK, and China. Many of the these plants are generating biogas from landfill, wastewater, fuel crops, and to a lesser extent from livestock manure. 


\subsection{Current Technology Developments and Practices for Rice Straw AD}

\subsubsection{Rice Straw Pretreatment for AD}

Pretreatment methods to improve the anaerobic digestion process were presented in many studies, such as Ngan (2012), Pilli et al. (2011), Hendriks and Zeeman (2009), Neyens et al. (2003), Weemaes and Verstraete (1998), Stuckey and McCarty (1984), and Haug et al. (1978). Pretreatment has been reported as an important step in the methane production process (Alvira et al. 2010; Carvalheiro et al. 2008; Taherzadeh and Karimi 2008). Pretreatment will change the structure of cellulose so that the enzymes can easily convert high molecular weight molecules, such as carbohydrates into simple sugars (Mosier et al. 2005). Especially in the case of rice straw, a biomass with a high-lignin pretreatment step is necessary to amplify the degradability of rice straw and speed up the anaerobic digestion process.

Rice straw pretreatment methods are classified as physical (particle size reduction), chemical (acid and alkali additions), and biological (fungi).

\subsubsection{Physical Pretreatment: Effect of Particle Size of Rice Straw}

Pretreatment of the feedstock can increase its solubility, consequently increasing biogas production and enhancing reduction of volatiles and solids content. Pretreatment is especially helpful in the digestion of biomass substrates as these substances tend to have high cellulose or lignin content. Additives can increase the production rate of the reactor or increase the startup speed, but their additional cost must always be balanced against improvements in efficiency (Ward et al. 2008; Ngan 2012).

Rice straw particle size reduction breaks the cell walls and makes the organic substrate more readily available for microbes to decompose (Zhang and Zhang 1999). Size reduction of rice straw increases surface area and breaks down its polymer structure, thereby increasing hydrolysis yield and hydrolysis rate during digestion (Hendriks and Zeeman 2009). Gharpuray et al. (1983) verified that pretreatment of wheat straw by ball-milling was found to be effective in increasing specific surface area $\left(2.3 \mathrm{~m}^{2} \mathrm{~g}^{-1}\right.$ for pretreated substrate compared to $0.64 \mathrm{~m}^{2} \mathrm{~g}^{-1}$ for raw straw). Fiber degradation and methane yield are enhanced when particle size is reduced from $100 \mathrm{~mm}$ to 2 (Mshandete et al. 2006). Consequently, methane yield increased (5-25\%) and digestion time was reduced (23-59\%) (Hendriks and Zeeman 2009). A study by Zhang and Zhang (1999) revealed that rice straw cut in 25-mm lengths has higher methane (198 $\mathrm{L} \mathrm{kg}^{-1} \mathrm{VS}$ ) versus uncut rice straw. However, addition of a milling step in the $\mathrm{AD}$ process is expensive due to its high energy requirements (Hendriks and Zeeman 2009).

Møller et al. (2004) observed, for rice straw AD, the increase in methane yield from 30-mm lengths (145 $\mathrm{L} \mathrm{kg}^{-1} \mathrm{VS}$ added) compared to 1 -mm lengths (161 $\mathrm{L} \mathrm{kg}^{-1}$ VS added) was significant after 60 days of digestion. Increased bio-degradability of 
rice straw has been demonstrated when methane production yield was found 7.9 and $13 \%$ higher, respectively, for sizes of 0.30 and $0.75 \mathrm{~mm}$ compared to $1.5 \mathrm{~mm}$ (Chandra et al. 2015). Sharma et al. (1988) reported that methane production tends to increase by from 43.5 to $52.0 \%$ when the particle size was gradually reduced from $30 \mathrm{~mm}$ to $0.088 \mathrm{~mm}$. However, rice straw sizes under $0.5 \mathrm{~mm}$ could be detrimental to the methane production process due to excessive accumulation of volatile fatty acids (VFAs) that will reduce $\mathrm{pH}$ in biogas reactor, causing inhibition of anaerobic organisms.

Methane production from rice straw with sizes of 2,5, and $10 \mathrm{~mm}$ illustrates that there is no significant difference among treatments, but compared to the untreated straw, methane production is from 8.3 to $9.3 \%$ higher. Comparing the methane yields of $\mathrm{AD}$ of rice straw of different sizes $(1,10,20 \mathrm{~cm}$, and original size) that was soaked in AD slurry for 5 days, it was found that there is no substantial difference in methane yields (166, 121, 166, and $168 \mathrm{~L} \mathrm{~kg}^{-1} \mathrm{VS}$ added, respectively) between treatments (Fig. 5.5).

Chopping and grinding rice straw into small particles less than $1 \mathrm{~mm}$ in size and mixing with kitchen waste and pig manure could produce methane from 205 to $384 \mathrm{~L} \mathrm{~kg}^{-1}$ VS added (Ye et al. 2013) whereas $2-3 \mathrm{~cm}$ of chopped rice straw with added micronutrients (nickel and cobalt at 10 and $15 \mathrm{mg} \mathrm{kg}^{-1}$, respectively) increased biogas production by 37 and $46 \%$ in mesophilic and thermophilic digesters, respectively.

\subsubsection{Chemical Pretreatment}

Chemical pretreatment methods mainly include acid and/or alkaline pretreatments.

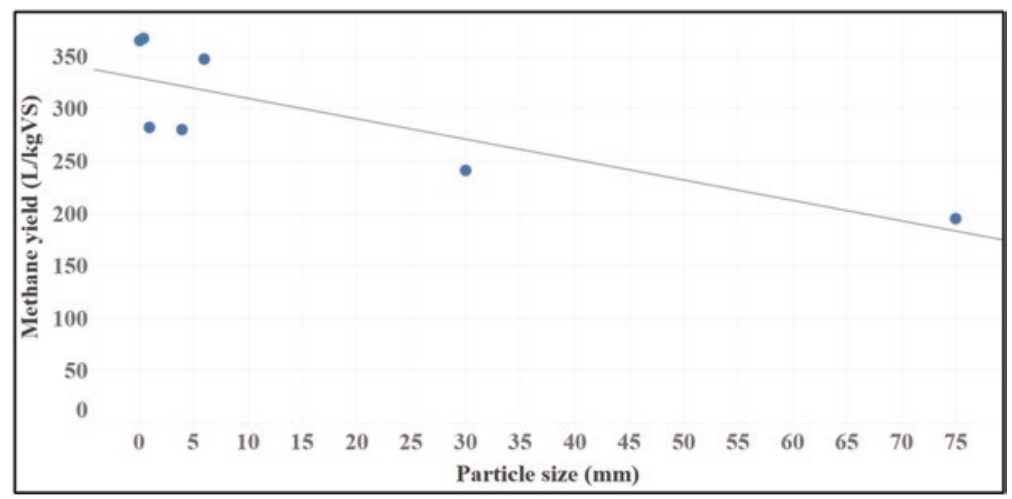

Fig. 5.5 Methane yields of rice straw at different particle sizes. Data sources: Ye et al. (2013), Menardo et al. (2012), Lei et al. (2010), Dinuccio et al. (2010), and Sharma et al. (1988) 


\subsection{Acid Pretreatment}

Acid pretreatment is desirable for anaerobic digestion of rice straw because it breaks down the lignin structure and helps methanogens acclimatize to low $\mathrm{pH}$ conditions.

- Hydrolysis by weak acid: acid pretreatment at low concentration is one of the most effective methods for treating lignocellulosic biomass. This method includes two types of hydrolysis: (1) continuous hydrolysis at high temperature (above $160{ }^{\circ} \mathrm{C}$ ) and a low loading rate (about 5-10\% TS), and (2) batch hydrolysis at low temperatures (below $160{ }^{\circ} \mathrm{C}$ ) with a high loading rate (about $10-40 \%$ TS). Acid sulfuric - sprayed into the lignocellulose, mixed, and then kept at from 160 to $200{ }^{\circ} \mathrm{C}$ for a few minutes-will remove hemicellulose. As a result, the efficiency of the hydrolysis process will be improved. Acid pretreatment showed the significant improvement of enzyme activity and removed hemicellulose effectively (Chen et al. 2007).

- Strong acid pretreatment: High concentrations of $\mathrm{H}_{2} \mathrm{SO}_{4}$ and $\mathrm{HCl}$ are widely used for pretreatment of lignocellulose because these acids are powerful and they help hydrolyze cellulose (Sun and Cheng 2002) without the involvement of enzymes in the hydrolysis process. The disadvantage of this method is the corrosive properties of these acids and they should be recycled to reduce pretreatment costs.

\subsection{Alkaline Pretreatment}

The main effect of alkaline pretreatment is lignin removal from rice straw, therefore improving the degradability of polysaccharides. In addition, alkaline pretreatment also eliminates acetyl and replaces uronic acid on hemicellulose, thereby increasing the enzyme activities on hemicellulose and cellulose surfaces.

- Pretreatment with ammonia solution: This is an effective treatment for lignocellulose. An ammonia solution is highly selective in reactions with lignin in comparison to carbohydrates. One of the reactions in an ammonia solution with lignin is the breakdown of the C-O-lignin as well as the ether and ester bonds in the lignin complex (Binod et al. 2010). However, this solution is an environmentally-polluting compound and a corrosive chemical.

- Pretreatment with calcium and sodium hydroxide: Lime $\left(\mathrm{Ca}(\mathrm{OH})_{2}\right)$ and sodium hydroxide $(\mathrm{NaOH})$ are commonly used for the pretreatment process. During the process. Salts can be formed and incorporated into materials (González et al. 1986). The condition of this process is quite simple but the reaction time is relatively long. This pretreatment results in high solubility of lignin, especially for materials with low lignin content such as softwoods and weeds. The addition of air or oxygen during the pretreatment process can improve the efficiency of the lignin decomposition (Chang and Holtzapple 2000). 


\subsubsection{Biological Pretreatment}

Biological pretreatment of feedstock for $\mathrm{AD}$ has attracted interest because it requires less energy input as compared with physical pretreatment and is less costly than chemical pretreatment, which costs more because of the expensive chemicals required. Hence, the biological route seems to be the most promising because it is an eco-friendly process and there is no inhibition during the process (Liu et al. 2014).

Rice straw is one of the most important biomass energy sources, largely because of its abundance. According to the Vietnam Statistical Yearbook (2018), around 23.63 million tons of rice straw are produced annually in the Mekong Delta, but more than $80 \%$ of it is burned on-site (Nguyen and Tran 2015). Typically, rice straw has a complex polymer crystal structure that is formed by the physical and chemical bonds among the cellulose, hemicellulose, and lignin components, which renders it difficult for anaerobic bacteria to utilize these components for biogas production (Sun et al. 2015). This becomes a major limitation to rice straw's efficient utilization.

Generally, methane yields from agricultural biomass are lower compared to conventional substrates, but agricultural biomass is an inexpensive option. Biological pretreatment methods can reduce anaerobic digestion duration, enhance feedstock digestibility, and increase gas production rate. This is because the lignocellulosic components of the straw are degraded into simple substances and made easy to digest in $\mathrm{AD}$, especially when using microorganisms with strong lignocellulose degradation ability. The key to the success of biological pretreatment is to find microorganisms that have exceptional lignin degradation ability and to determine the optimum digestion conditions for these microorganisms. Examples of biological pretreatment methods are: microaerobic treatments, ensiling or composting, separation of digestion stages, and fungi pretreatments.

Biological pretreatment of rice straw using fungi is a comparatively eco-friendly approach of enhancing degradability when compared with chemical pretreatment, which requires expensive chemicals, high energy inputs, and toxic substance removal, (Carrere et al. 2016). Several fungi species are used for pretreatment of lignocellulosic biomass for anaerobic digestion and most of them are the white-rot fungus (Ceriporiopsis subvermispora). A study by Zhao et al. (2014a, b) using white-rot fungus as the pretreatment agent increased methane yield by $5-15 \%$ as compared with untreated biomass.

Biological pretreatment is normally done by soaking the straw in a natural microbial solution obtained from the effluent of an anaerobic digester, anoxic sediment from ponds or lakes, and wastewater. One study found that rice straw pretreated by soaking in anoxic sediment and digester effluent for 5 days produced 79-85\% more biogas volume than straw soaked in tap water (Tran et al. 2017). Compared with untreated substrates, pretreatment using microbiological action increases the degradability of substrates. Yadav et al. (2019) verified that optimal conditions for the biological treatment of lignocellulose biomass of wheat straw by Chaetomium globosporum was found to be $36{ }^{\circ} \mathrm{C}, 31$ days, and $81 \%$ moisture, resulting in a 2.9-fold increase in reducing sugar, $48 \%$ removal of lignin, and $31 \%$ increase in biogas yield. 
Similarly, a study by Shen et al. (2018) on the effect of organic loading rate on anaerobic codigestion of rice straw and pig manure showed that after biological pretreatment, the substrate was optimally fermented at an organic loading rate of $2.5 \mathrm{~kg} \mathrm{COD} \mathrm{m}^{-3} \mathrm{day}^{-1}$. This pretreatment achieved the optimum volumetric methane production rate of $640 \mathrm{~L} \mathrm{CH}_{4} \mathrm{~m}^{-3}$ day $^{-1}$, and a methane yield of $456 \mathrm{~L} \mathrm{CH}_{4} \mathrm{~kg}^{-1}$ COD removed, which were 62.4 and $37.8 \%$ higher than those of the control under the same organic loading rate.

Using aerobic and anaerobic fungi as pretreatment agents resulted in increased biodegradability of rice straw (Ghosh and Bhattacharyya 1999; Cann et al. 1994). Methane production from rice straw AD was increased $31-46 \%$ when pretreating it with white-rot fungus and brown-rot fungus (Polyporus ostreiformis using a strawto-fungi ratio of $14: 1$ and then digested in batch reactors at $30{ }^{\circ} \mathrm{C}$ after a 3 -week incubation period. Cann et al. (1994) reported that the anaerobic fungi from the rumen consistently increased the digestibility of rice straw when compared with fermenters where the fungi were inhibited. Haruta et al. (2002) also presented the enhancements by a microbial community formed by mixing rice straw, chicken feces, pig feces, cattle feces, and sugarcane dregs. This degraded $60 \%$ of the rice straw within 4 days.

Momayez et al. (2018) presented an investigation using effluent of biogas digestate to pretreat rice straw. The straw was pretreated at different temperatures (130, 60 , and $190{ }^{\circ} \mathrm{C}$ ) at different pretreatment times (30 and $60 \mathrm{~min}$ ). The pretreated straw was subjected to different processes, including liquid anaerobic digestion (L-AD) and dry anaerobic digestion (D-AD). The highest methane yields were obtained through L-AD and D-AD of straw pretreated at $190{ }^{\circ} \mathrm{C}$ and $30 \mathrm{~min}$, resulting in 24 and $26 \%$ increases in methane produced as compared with L-AD and D-AD using untreated straw. Mustafa et al. (2016) showed that rice straw pretreated with fungi (Pleurotus ostreatus and Trichoderma reesei) and used as feedstock for AD improved the methane yield by 120 and 78.3\%, respectively, as compared with untreated straw. These points of view show that biological pretreatment studies have a huge potential, considering that there were only a few fungi species that were studied. There are still millions of fungi species that are yet to be studied.

The results of the previous research mentioned above are shown in Fig. 5.6.

\subsubsection{Current Practices of Rice Straw AD}

Continuous farm-scaled AD with a plastic digester was assessed and reported by Tran et al. (2015). Figure 5.7a, b show the schematic diagram of the rice straw AD system using a biogas bag developed by Can Tho University in Vietnam. The 6- $\mathrm{m}^{3}$ household digester is made of high-density polyethylene (HDPE). Rice straw was cut in 20-cm lengths and ensilaged about 5 days before feeding into the digester. The cofeeding of rice straw and pig dung with the mixed ratio was 1:1 based on the organic dry matter (ODM). The daily feed of rice straw was $4.75 \mathrm{~kg}$ dry weight (DW) corresponding to $4.17 \mathrm{~kg}$ DW of pig dung. Retention time of rice straw in this 


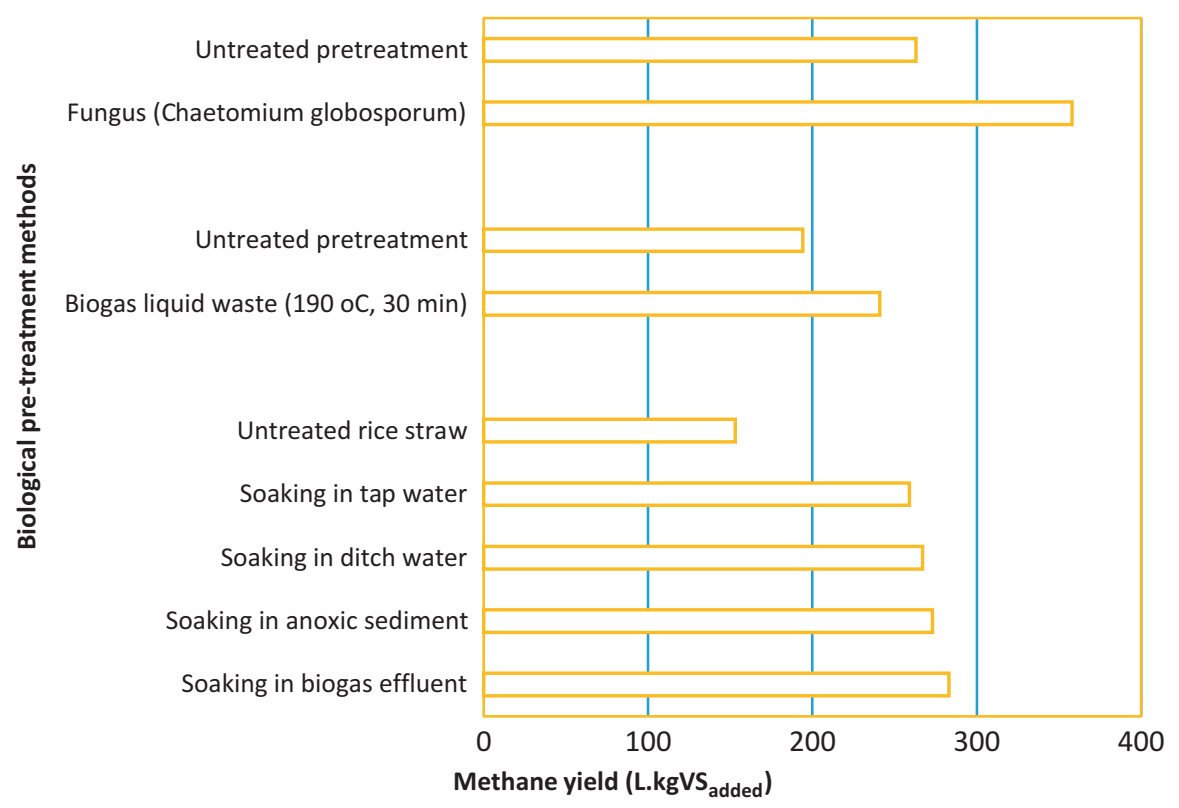

Fig. 5.6 Biological pretreatment methods of rice straw for biogas production

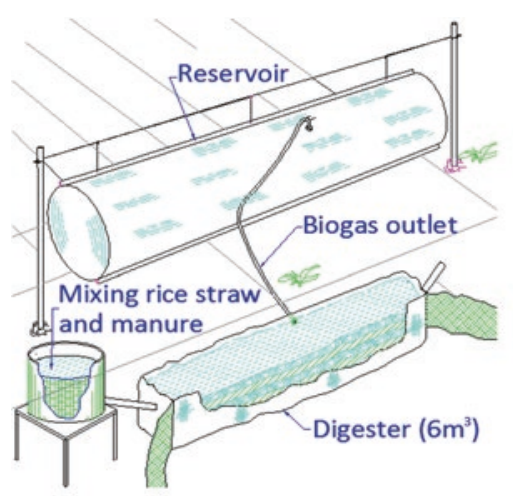

(a)

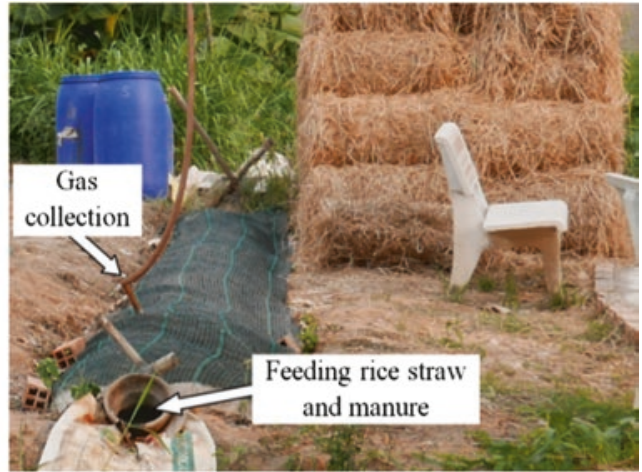

(b)

Fig. 5.7 Continuous farm-scale AD: (a) isometric cut-away view; (b) as practices in Vietnam

$\mathrm{AD}$ was from 110 to 120 days. Average biogas yield was $600 \mathrm{~L} \mathrm{~kg}^{-1} \mathrm{ODM}$ fermented. Some constraints of this technology are the $\mathrm{pH}$ value dropping due to the cumulative total of volatile fatty acids (TVFAs), short-retention time due to accumulated rice straw inside the digester, and limited skill of management that may cause biogas leaking and environmental harm. 
In current models, the rice straw floats on the surface of the substrate and gets stuck. Scientists at Can Tho University are testing a new HDPE model, which could prevent the floating straw by adjusting the inlet and outlet balance level. This upgrade could also improve the short retention time of the straw as well.

\subsubsection{Rice Straw Batch AD}

This technology was developed at IRRI (RKB, accessed 2019) by Nguyen et al. (2016) using a hermetic bag (so called IRRI super bag) to make the digesters. This plastic batch-AD is shown in Fig. 5.8a, b. Rice straw and carabao dung are arranged in layers in the digester. Rice straw is spread on the first layer then covered by a dung layer. This is repeated with cattle dung on the top to cover all substrates.

Biogas yield was in the range of $211-779 \mathrm{~L} \mathrm{~kg}^{-1}$ ODM. This experiment illustrated the following advantages of the IRRI super-bag AD: (1) the capital requirement is low with bags costing US\$ 3 each, (2) floating rice straw is avoided; (3) it is portable; and (4) the digester contents are easy to unload after digestion is finished.

\subsubsection{Two-Stage AD}

Based on the assessment and verification of AD industrial technology, the pilot of a two-stage AD system was designed and is being tested at IRRI. Figure 5.9 shows the schematic diagram of the system with the following characteristics:

- Two-stage AD;

- Digestion temperature is maintained at from 35 to $55^{\circ} \mathrm{C}$;

- Feedstock: chopped or sheared rice straw mixed with animal manure based on the ratio of 75 and $25 \%$ of organic dry matter, respectively;

- Outputs: biogas for generating heat or power and digestate to produce solid and liquid fertilizer.

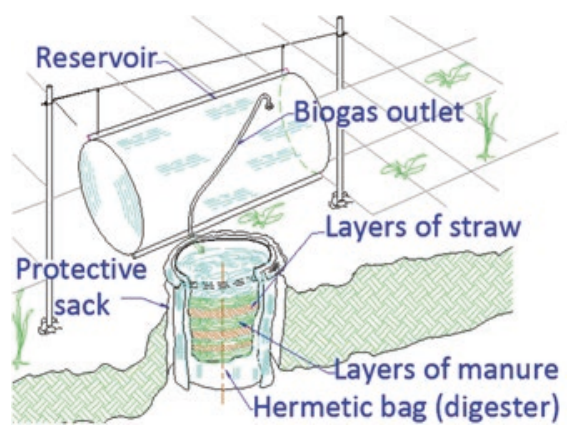

(a)

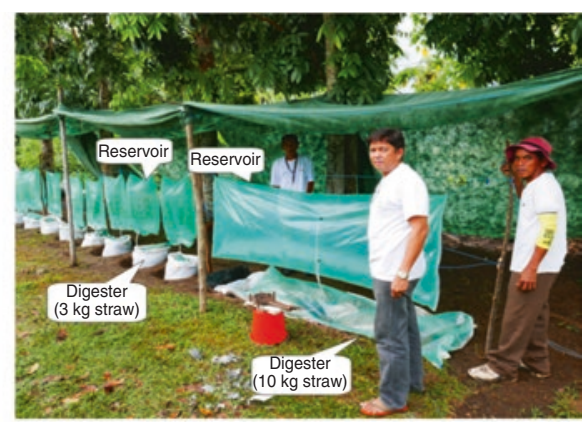

(b)

Fig. 5.8 Plastic batch-AD: (a) isometric cut-away view, (b) as practiced at IRRI 


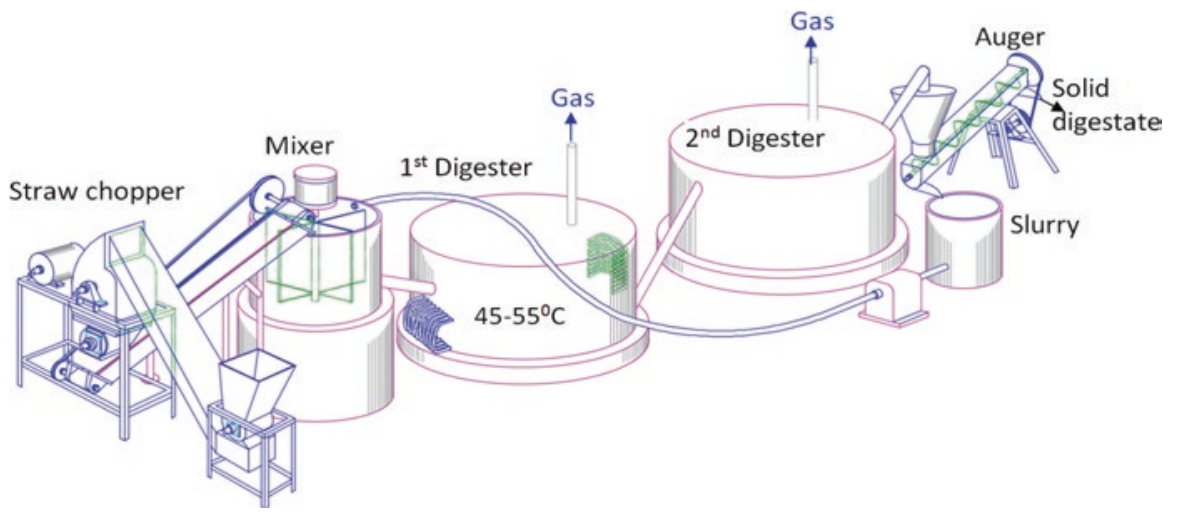

Fig. 5.9 Schematic diagram of the two-stage AD

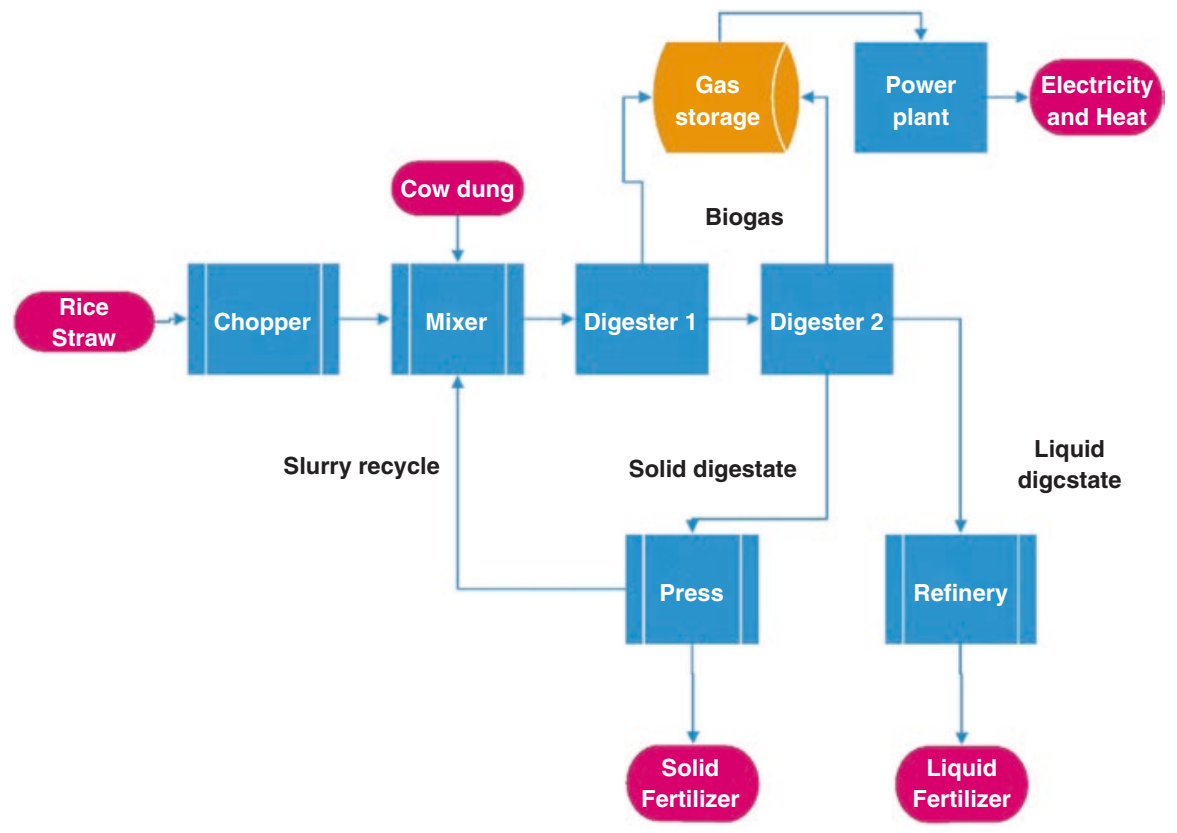

Fig. 5.10 Process route of AD power plant in Fazilka, Punjab, India

Figure 5.10 shows the process route of the biogas power plant using rice straw feedstock, which is located at Fazilka in Punjab, India. Rice straw is fed into a chopper to be sheared off. The sheared rice straw is mixed with $25 \%$ cow dung in weight and pumped into the first stage $2000-\mathrm{m}^{3}$ digester, which is maintained at $35^{\circ} \mathrm{C}$. Retention time (RT) of the substrate in the first anaerobic digestion (AD) stage is 20 days and then conveyed into the second-stage digester, also $2000 \mathrm{~m}^{3}$ and maintained at $35{ }^{\circ} \mathrm{C}$ with an RT of 20 days. The biogas is collected through a 
reservoir and then converted to electric power by a generator. The digestate after $\mathrm{AD}$ is used for processing organic fertilizers.

\subsection{Utilization of Bioslurry}

Applications of bioslurry on crops have been investigated since the 1940s. Gurung (1997) showed that bioslurry had a better effect on crops compared to farmyard manure. This study also revealed that $\mathrm{AD}$ converts $25-30 \%$ of the organic part of fecal matter into biogas, while 70-75\% goes to the effluent or bioslurry.

Nutrients (N-P-K) and micronutrients (zinc, iron, manganese, and copper) in bioslurry are needed for plant growth (Tripathi 1993 as cited by Gurung 1997). Bunyeth and Preston (2004) and Sophea and Preston (2001) reported that water spinach yield responded linearly to increasing levels of nitrogen in bioslurry with pig manure. The yield of leaf mustard fertilized by the codigester effluent was 2.2 times higher compared to the inorganic fertilizer treatment. In addition to increasing the yield, the effluent can help retain more nutrients in the soil layer, accelerate flower formation, and shorten cultivation time (Nguyen et al. 2015).

Using bioslurry for fisheries was also reported in several studies. Kaur et al. (1987) presented that the growth rate of carp was 3.5 times higher in the bioslurry tank than in the control tank with raw cow dung. Increases in fish growth rate using biogas effluent were also revealed by Balasubramanian and Bai (1994) and Sophin and Preston (2001).

\subsection{Conclusions and Recommendations}

This review of the $\mathrm{AD}$ process, including $\mathrm{AD}$ systems from different countries, provides an overview of the current practices and trends. It should be noted that there is no such thing as a best digester design as the technology is often highly localized. $\mathrm{An} \mathrm{AD}$ technology may work well in one country but not in another because of different conditions.

With regards to the use of rice straw for $\mathrm{AD}$, studies have shown that it is a feasible and sustainable technology, especially when rice straw is codigested with other biological wastes such as animal manure. Using the optimum pretreatment, conditions, and operational parameters and a mixture proportion with other substrates, methane production from $\mathrm{AD}$ of rice straw can be maximized. In addition, the digestate byproduct can be processed to produce biofertilizer.

To increase the adoption of $\mathrm{AD}$ technologies, awareness of the technology must be increased and the rice straw and biogas value chain must be upgraded. AD technologies that are easy to adopt, such as the use of hermetic bags for $\mathrm{AD}$, can be useful to farmers. Subsequent increase in demand for biogas and biofertilizers can be supported by larger scale technologies such as the two-stage AD. 


\section{References}

Ahn JH, Do TH, Kim S, Hwang S (2006) The effect of calcium on the anaerobic digestion treating swine wastewater. Biochem Eng J 30(1):33-38

Alhraishawi A, Alani W (2018) The cofermentation of organic substrates: A review performance of biogas production under different salt content. Paper presented at the sixth scientific conference, renewable energy and its applications, pp 1-14

Allen MR, Braithwaite A, Hills CC (1997) Trace organic compounds in landfill gas at seven UK waste disposal sites. Environ Sci Technol 31(4):1054-1061

Alvira P, Tomas-Pejo E, Ballesteros M, Negro MJ (2010) Pretreatment technologies for an efficient bioethanol production process based on enzymatic hydrolysis: a review. Bioresour Technol 101(13):4851-4861

Angelidaki I, Ahring B (1992) Effects of free long-chain fatty acids on thermophilic anaerobic digestion. Appl Microbiol Biotechnol 37(6):808-812

Anwar N, Wang W, Zhang J, Li Y, Chen C, Liu G, Zhang R (2016) Effect of sodium salt on anaerobic digestion of kitchen waste. Water Sci Technol 73(8):1865-1871

Arvanitoyannis IS, Tserkezou P (2008) Corn and rice waste: a comparative and critical presentation of methods and current and potential uses of treated waste. Int J Food Sci Technol 43(6):958-988

Balasubramanian P, Bai RK (1994) Biogas-plant effluent as an organic fertiliser in fish polyculture. Bioresour Technol 50(3):189-192

Balasubramaniyam U, Zisengwe LS, Meriggi N, Buysman E (2008) Biogas production in climates with long cold winters. WECF, Wageningen

Bardiya N, Gaur A (1997) Effects of carbon and nitrogen ratio on rice straw biomethanation. J Rural Energy 4(1-4):1-16

Binod P, Sindhu R, Singhania RR, Vikram S, Devi L, Nagalakshmi S, Kurien N, Sukumaran RK, PandeyA (2010) Bioethanol production from rice straw: an overview. Bioresour Technol, 101(13):4767-4774

Biosantech TAS, Rutz D, Janssen R, Drosg B (2013) Biomass resources for biogas production. The Biogas Handbook, In, pp 19-51

Bunyeth H, Preston T (2004) Biodigester effluent as fertilizer for water spinach established from seed or from cuttings. Livest Res Rural Dev 16(10)

Cann I, Kobayashi Y, Wakita M, Hoshino S (1994) Effects of three chemical treatments on in vitro fermentation of rice straw by mixed rumen microbes in the presence or absence of anaerobic rumen fungi. Reprod Nutr Dev 34(1):47-56

Carrere H, Antonopoulou G, Affes R, Passos F, Battimelli A, Lyberatos G, Ferrer I (2016) Review of feedstock pretreatment strategies for improved anaerobic digestion: from lab-scale research to full-scale application. Bioresour Technol 199:386-397

Carvalheiro F, Duarte LC, Gírio FM (2008) Hemicellulose biorefineries: a review on biomass pretreatments. J Sci Indust Res:849-864

Chandra R, Takeuchi H, Hasegawa T (2012) Methane production from lignocellulosic agricultural crop wastes: a review in context to second generation of biofuel production. Renew Sust Energ Rev 16(3):1462-1476

Chandra R, Takeuchi H, Hasegawa T, Vijay V (2015) Experimental evaluation of substrate's particle size of wheat and rice straw biomass on methane production yield. Agric Eng Int CIGR J 17(2):93-104

Chang VS, Holtzapple MT (2000) Fundamental factors affecting biomass enzymatic reactivity. Paper presented at the Twenty-first symposium on biotechnology for fuels and chemicals

Chen Y, Sharma-Shivappa RR, Chen C (2007) Ensiling agricultural residues for bioethanol production. Appl Biochem Biotechnol 143(1):80-92

Chen Y, Cheng JJ, Creamer KS (2008) Inhibition of anaerobic digestion process: a review. Bioresour Technol 99(10):4044-4064

Clark R, Speece R (1971) The pH tolerance of anaerobic digestion. Adv Water Pollut Res 1:1-13 
Deublein D, Steinhauser A (2011) Biogas from waste and renewable resources : an introduction, 2nd, rev. and expanded ed. Wiley-VCH, Weinheim

Dinuccio E, Balsari P, Gioelli F, Menardo S (2010) Evaluation of the biogas productivity potential of some Italian agro-industrial biomasses. Bioresour Technol 101(10):3780-3783

Eastman JA, Ferguson JF (1981) Solubilization of particulate organic carbon during the acid phase of anaerobic digestion. J Water Pollut Cont Fed 53(3):352-366

Eder B, Krieg A, Schulz H (2006) Biogas-Praxis: Grundlagen, Planung, Anlagenbau, Beispiele, Wirtschaftlichkeit: Ökobuch-Verlag

Fang C, Boe K, Angelidaki I (2011) Anaerobic codigestion of desugared molasses with cow manure; focusing on sodium and potassium inhibition. Bioresour Technol 102(2):1005-1011

Gerardi MH (2003) The microbiology of anaerobic digesters. Wiley, Hoboken

Gharpuray M, Lee YH, Fan L (1983) Structural modification of lignocellulosics by pretreatments to enhance enzymatic hydrolysis. Biotechnol Bioeng 25(1):157-172

Ghosh A, Bhattacharyya B (1999) Biomethanation of white rotted and brown rotted rice straw. Bioprocess Eng 20(4):297-302

Gollakota K, Meher K (1988) Effect of particle size, temperature, loading rate, and stirring on biogas production from castor cake (oil expelled). Biol Wastes 24(4):243-249

González G, López-Santín J, Caminal G, Sola C (1986) Dilute acid hydrolysis of wheat straw hemicellulose at moderate temperature: a simplified kinetic model. Biotechnol Bioeng 28(2):288-293

Gu Y, Chen X, Liu Z, Zhou X, Zhang Y (2014) Effect of inoculum sources on the anaerobic digestion of rice straw. Bioresour Technol 158:149-155

Gunnerson CG, Stuckey DC, Greeley M, Skrinde R (1986) Anaerobic digestion: principles and practices for biogas systems. World Bank technical paper No. 49. The World Bank, Washington DC, United State

Gurung J B (1997) Review of literature on effects of slurry use on crop production. The Biogas Support Programme, Kathmandu, Nepal

Haruta S, Cui Z, Huang Z, Li M, Ishii M, Igarashi Y (2002) Construction of a stable microbial community with high cellulose-degradation ability. Appl Microbiol Biotechnol 59(4-5):529-534

Haug RT, Stuckey DC, Gossett JM, McCarty PL (1978) Effect of thermal pretreatment on digestibility and dewaterability of organic sludges. J Water Pollut Contr Feder 50(1):73-85

Hendriks AT, Zeeman G (2009) Pretreatments to enhance the digestibility of lignocellulosic biomass. Bioresour Technol 100(1):10-18

Hills DJ (1981) Anaerobic digestion of dairy manure and field crop residues. Agric Wastes 3:179-189

Jönsson O, Polman E, Jensen JK, Eklund R, Schyl H, Ivarsson S (2003) Sustainable gas enters the European gas distribution system. Raport Danish Gas Technology Center

Jördening H-J, Winter J (2006) Environmental biotechnology: concepts and applications. Wiley, New York

Kargi F, Dincer AR (1996) Effect of salt concentration on biological treatment of saline wastewater by fed-batch operation. Enzym Microb Technol 19(7):529-537

Kaur K, Sehgal GK, Sehgal H (1987) Efficacy of biogas slurry in carp, Cyprinus carpio var. communis (Linn.), culture-effects on survival and growth. Biol Wastes 22(2):139-146

Koster I, Lettinga G (1988) Anaerobic digestion at extreme ammonia concentrations. Biol Wastes 25(1):51-59

Kugelman IJ, McCarty PL (1965) Cation toxicity and stimulation in anaerobic waste treatment. J Water Poll Control Federation:97-116

Laanbroek H (1990) Bacterial cycling of minerals that affect plant growth in waterlogged soils: a review. Aquat Bot 38(1):109-125

Lee DH, Behera SK, Kim JW, Park HS (2009) Methane production potential of leachate generated from Korean food waste recycling facilities: a lab-scale study. Waste Manag 29:876-882

Lei Z, Chen J, Zhang Z, Sugiura N (2010) Methane production from rice straw with acclimated anaerobic sludge: effect of phosphate supplementation. Bioresour Technol 101(12):4343-4348 
Li D, Liu S, Mi L, Li Z, Yuan Y, Yan Z, Liu X (2015) Effects of feedstock ratio and organic loading rate on the anaerobic mesophilic codigestion of rice straw and cow manure. Bioresour Technol 189:319-326

Lianhua L, Dong L, Yongming S, Longlong M, Zhenhong Y, Xiaoying K (2010) Effect of temperature and solid concentration on anaerobic digestion of rice straw in South China. Int J Hydrog Energy 35(13):7261-7266

Lim JS, Abdul Manan Z, Wan Alwi SR, Hashim H (2012) A review on utilisation of biomass from rice industry as a source of renewable energy. Renew Sust Energ Rev 16(5):3084-3094

Liu S, Wu S, Pang C, Li W, Dong R (2014) Microbial pretreatment of corn stovers by solid-state cultivation of Phanerochaete chrysosporium for biogas production. Appl Biochem Biotechnol 172(3):1365-1376

Makádi M, Tomócsik A, Orosz V (2012) Digestate: a new nutrient source: review. In: Biogas: IntechOpen

Malik R, Singh R, Tauro P (1987) Effect of inorganic nitrogen supplementation on biogas production. Biol Wastes 21(2):139-142

McCarty PL (1964) Anaerobic waste treatment fundamentals. Public Works 95(9):107-112

Menardo S, Airoldi G, Balsari P (2012) The effect of particle size and thermal pretreatment on the methane yield of four agricultural by-products. Bioresour Technol 104:708-714

Møller HB, Sommer SG, Ahring BK (2004) Methane productivity of manure, straw, and solid fractions of manure. Biomass Bioenergy 26(5):485-495

Momayez F, Karimi K, Horváth IS (2018) Enhancing ethanol and methane production from rice straw by pretreatment with liquid waste from biogas plant. Energy Convers Manag 178:290-298

Monnet F (2003) An introduction to anaerobic digestion of organic wastes. Remade Scotland

Moorhead K, Nordstedt R (1993) Batch anaerobic digestion of water hyacinth: effects of particle size, plant nitrogen content, and inoculum volume. Bioresour Technol 44(1):71-76

Mosier N, Wyman C, Dale B, Elander R, Lee Y, Holtzapple M, Ladisch M (2005) Features of promising technologies for pretreatment of lignocellulosic biomass. Bioresour Technol 96(6):673-686

Mshandete A, Björnsson L, Kivaisi AK, Rubindamayugi MS, Mattiasson B (2006) Effect of particle size on biogas yield from sisal fibre waste. Renew Energy 31(14):2385-2392

Mustafa AM, Poulsen TG, Sheng K (2016) Fungal pretreatment of rice straw with Pleurotus ostreatus and Trichoderma reesei to enhance methane production under solid-state anaerobic digestion. Appl Energy 180:661-671

Neyens E, Baeyens J, Creemers C (2003) Alkaline thermal sludge hydrolysis. J Hazard Mater 97(1-3):295-314

Ngan NVC (2012) Promotion of biogas plant application in the Mekong Delta of Vietnam. PhD dissertation. Technical University of Braunschweig

Ngan NVC, Viet LH, Cu ND, Phong NH (2011) Biogas production of pig manure with water hyacinth juice from batch anaerobic digestion. In: Environmental Change and Agricultural Sustainability in the Mekong Delta, pp 355-369

Nguyen VCN, Tran SN (2015) Greenhouse gas emmission from on-field straw burning in the Mekong Delta of Vietnam. In: Proceedings of 8th Asian Crop Science Association Conference, pp 43-50

Nguyen VCN, Phan NL, Nguyen TNL, Pham CM, Kieu TN (2015) Cobenefits from applying codigester's bio-slurry to farming activities in the Mekong Delta. Health Environ 1:30-44

Nguyen VH, Castalone A, Jamieson C, Gummert M (2016) Small-scale batch anaerobic digestion of rice straw. https://waset.org/pdf/books/?id=54846\&pageNumber=1

Nianguo L (1984) Biogas in China. Trends Biotechnol 2(3):77-79

Nozhevnikova A, Kotsyurbenko O, Parshina S (1999) Anaerobic manure treatment under extreme temperature conditions. Water Sci Technol 40(1):215-221

Ogata Y, Ishigaki T, Nakagawa M, Yamada M (2016) Effect of increasing salinity on biogas production in waste landfills with leachate recirculation: a lab-scale model study. Biotechnol Reports 10:111-116 
Parkin G F, Lynch NA, Kuo WC, Van Keuren EL, Bhattacharya SK (1990) Interaction between sulfate reducers and methanogens fed acetate and propionate. Res J Water Pollut Contr Feder:780-788

Pilli S, Bhunia P, Yan S, LeBlanc R, Tyagi R, Surampalli R (2011) Ultrasonic pretreatment of sludge: a review. Ultrason Sonochem 18(1):1-18

Polprasert C, Koottatep T (2007) Organic waste recycling. IWA Publishing, London

Rasi S, Veijanen A, Rintala J (2007) Trace compounds of biogas from different biogas production plants. Energy 32(8): 1375-1380

Reinhart D, Townsend T (1998) Landfill bioreactor design and operation. CRC Press LLC, Boca Raton

Sharma SK, Mishra I, Sharma M, Saini J (1988) Effect of particle size on biogas generation from biomass residues. Biomass 17(4):251-263

Shen F, Li H, Wu X, Wang Y, Zhang Q (2018) Effect of organic loading rate on anaerobic codigestion of rice straw and pig manure with or without biological pretreatment. Bioresour Technol 250:155-162

Singh KJ, Sooch SS (2004) Comparative study of economics of different models of family size biogas plants for state of Punjab, India. Energy Convers Manag 45(9-10):1329-1341

Sophea K, Preston T (2001) Comparison of biodigester effluent and urea as fertilizer for water spinach vegetable. Livest Res Rural Dev 13(6):125-127

Sophin P, Preston T (2001) Effect of processing pig manure in a biodigester as fertilizer input for ponds growing fish in polyculture. Livest Res Rural Dev 13(6)

Spiegel RJ, Preston JL (2003) Technical assessment of fuel cell operation on anaerobic digester gas at the Yonkers, NY, wastewater treatment plant. Waste Manag 23(8):709-717

Stuckey DC, McCarty PL (1984) The effect of thermal pretreatment on the anaerobic biodegradability and toxicity of waste activated sludge. Water Res 18(11):1343-1353

Sun Y, Cheng J (2002) Hydrolysis of lignocellulosic materials for ethanol production: a review. Bioresour Technol 83(1):1-11

Sun C, Liu R, Cao W, Yin R, Mei Y, Zhang L (2015) Impacts of alkaline hydrogen peroxide pretreatment on chemical composition and biochemical methane potential of agricultural crop stalks. Energy Fuel 29(8):4966-4975

Taherzadeh M, Karimi K (2008) Pretreatment of lignocellulosic wastes to improve ethanol and biogas production: a review. Int J Mol Sci 9(9):1621-1651

Thanh PV (2010) VAC integrated system with entire energy chain in Vietnam. Paper presented at the FAO technical consultation conference

Tran SN, Vo TV, Nguyen HC, Nguyen VCN, Le HV, Ingvorsen K (2014) Enhancing biogas production by supplementing rice straw. J Sci Technol 52(3A):294-301

Tran SN, Huynh VT, Huynh CK, Nguyen VCN, Nguyen HC, Le HV, Kjeld I (2015) Evaluation the possibility of using rice straw and water hyacinth in semi continuous anaerobic fermentation: the application on farm-scale polyethylene biogas digesters. Can Tho University J Sci 36:27-35. (in Vietnamese)

Tran SN, Nguyen VCN, Nguyen HC, Le HV, Ingvorsen K (2017) Rice straw pretreatment methodology for biogas production. In: Rice straw in the Mekong Delta of Vietnam and its potential for biogas production. $\mathrm{p}$ 61-84 (in Vietnamese)

Tripathi A (1993) Biogas slurry: a boon for agriculture crops. Biogas slurry utilisation. CORT, New Delhi, pp 11-14

Wang Y, Zhang Y, Meng L, Wang J, Zhang W (2009) Hydrogen-methane production from swine manure: effect of pretreatment and VFAs accumulation on gas yield. Biomass Bioenergy 33(9):1131-1138

Ward AJ, Hobbs PJ, Holliman PJ, Jones DL (2008) Optimisation of the anaerobic digestion of agricultural resources. Bioresour Technol 99(17):7928-7940

Weemaes MP, Verstraete WH (1998) Evaluation of current wet sludge disintegration techniques. J Chem Technol Biotechnol: Intl Res Proc Environ Clean Technol 73(2):83-92 
Wiese J, König R (2009) From a black-box to a glass-box system: the attempt towards a plant-wide automation concept for full-scale biogas plants. Water Sci Technol 60(2):321-327

Yadav M, Singh A, Balan V, Pareek N, Vivekanand V (2019) Biological treatment of lignocellulosic biomass by Chaetomium globosporum: process derivation and improved biogas production. Int J Biol Macromol 128:176-183

Yadvika S, Sreehrishnan TR, Kohli S, Rana V (2004) Enhancement of biogas production from solid substrates using different techiniques - a review. Bioresour Technol 95:1-10

Yan Z, Song Z, Li D, Yuan Y, Liu X, Zheng T (2015) The effect of initial substrate concentration, $\mathrm{C} / \mathrm{N}$ ratio and temperature on solid-state anaerobic digestion for composting straw. Bioresour Technol 177:266-273

Ye J, Li D, Sun Y, Wang G, Yuan Z, Zhen F, Wang Y (2013) Improved biogas production from rice straw by codigestion with kitchen waste and pig manure. Waste Manag 33(12):2653-2658

Zhang R, Zhang Z (1999) Biogasification of rice straw with an anaerobic-phased solids digester system. Bioresour Technol 68(3):235-245

Zhao J, Ge X, Vasco-Correa J, Li Y (2014a) Fungal pretreatment of unsterilized yard trimmings for enhanced methane production by solid-state anaerobic digestion. Bioresour Technol 158:248-252

Zhao J, Zheng Y, Li Y (2014b) Fungal pretreatment of yard trimmings for enhancement of methane yield from solid-state anaerobic digestion. Bioresour Technol 156:176-181

Ziemiński K, Frąc M (2012) Methane fermentation process as anaerobic digestion of biomass: transformations, stages, and microorganisms. Afr J Biotechnol 11(18):4127-4139

Zinder SH (1993) Physiological ecology of methanogens. In: Methanogenesis, pp 128-206. Springer, Berlin

Open Access This chapter is licensed under the terms of the Creative Commons Attribution 4.0 International License (http://creativecommons.org/licenses/by/4.0/), which permits use, sharing, adaptation, distribution and reproduction in any medium or format, as long as you give appropriate credit to the original author(s) and the source, provide a link to the Creative Commons licence and indicate if changes were made.

The images or other third party material in this chapter are included in the chapter's Creative Commons licence, unless indicated otherwise in a credit line to the material. If material is not included in the chapter's Creative Commons licence and your intended use is not permitted by statutory regulation or exceeds the permitted use, you will need to obtain permission directly from the copyright holder.

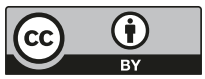

